\title{
Hair Texture Improvement owing to Treatment
}

Ju-Sub Kim

Department of Cosmetology, Sangji Youngseo College, Wonju-si, Gangwon-do, Korea

Corresponding author: Ju-Sub Kim, Department of Cosmetology, Sangji Youngseo College, 84 Sangjidae-gil, Wonju-si, Gangwondo 26339 , Korea

Tel.: +82337300811

Fax: +82337300811

Email: c-miro@hanmail.net

Received December 1, 2016

Revised January 11, 2017

Accepted January 17, 2017

Published March 30, 2017

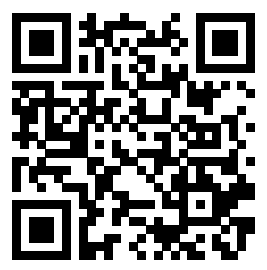

\begin{abstract}
Purpose: This research investigates how much hair quality could be improved through the use of a hair-treatment agent produced by adding amino acids such as cystine, lysine, proline, arginine, glutamine acid, and alanine. Methods: The research was implemented through measuring hair surface arrangements, amino acid contents, and tensile strength. The following procedure was taken as a research method. Firstly, we prepared bleached and dyed hair, which were based on healthy hair. Secondly, we applied a hair-treatment agent on them as follows: plain shampoo, hair treatment after plain shampoo (once), hair treatment after plain shampoo (twice). Thirdly, we measured absorbance of methylene blue (MB), amino acid contents, and tensile strength. Results: The value of absorbance was lowered and amino acid contents was increased, according to the number of using a hair-treatment agent. The value of tensile strength was increased in the event of applying a hair-treatment agent. Conclusion: We could find that there was improvement of hair quality under the condition of applying a hair-treatment agent rather than that of using a plain shampoo. Thus, hair-treatment agents could be developed as a new product for home use and use by professionals.
\end{abstract}

Keywords: Treatment, Hair, Improvement, Texture, Cuticle

\section{Introduction}

개인의 아름다움을 표현하는 방법에는 메이크업, 패션, 헤어스 타일 등이 있으며 헤어스타일에 있어 자신의 아름다움을 표현하 는 방법에는 커트, 퍼머넌트 웨이브, 모발 염색 등이 있다(Kim \& Choe, 2010). 인간에 있어서 모발의 기능 중 미적 장식의 기능은 개인의 이미지 연출에 중요한 역할을 하고, 특히 모발의 형태와 아 름다운 칼라는 또 하나의 중요한 수단이 되었다(quoted in Jeong et al., 2000). 그러나 아름다움을 위해 여러 가지 미용 시술을 함으 로써 모발의 모표피 손상, 아미노산 함량 감소, 인장강도 감소 등의 물리 · 화학적 손상이 발생한다.

미용 시술 중 염색은 아닐린 염료와 같은 합성염모제의 발달로 인하여 비약적인 발전을 이루었다. 염료를 산화제와 혼합하여 모발 에 도포하면, 1 제의 암모니아는 모발의 표면을 부풀리고, 연화시키 는 작용으로 혼합액이 모피질로 들어가 화학반응을 일으켜 산화제 의 산소와 혼합하여 발색이 일어난다(Kim et al., 2006). 이러한 화 학반응이 일어나는 과정에서 1제의 암모니아와 2 제의 과산화수소 수에 의해 모발이 팽윤, 연화되는 과정에서 모발의 모표피가 일어
나고, 모피질 성분이 빠져 나가는 모발의 손상이 야기 된다. 그 결 과, 큐티클이 일어나 다른 모발과 엉켜 빗질이 안 되고, 유분과 수 분이 빠져나가 모발이 거칠어 보일 뿐만 아니라 푸석 푸석한 상태 가 된다(Kim et al., 2010).

탈색제 역시 멜라닌 색소를 파괴함과 동시에 모발 성분을 용해 시켜 모발에 빈 공간을 만들 뿐만 아니라 모표피가 박리하는 등의 모발 손상을 일으킨다(Kim et al., 2010; Lee et al., 2006). 이와 같이 미용을 위하여 모발에 물리 · 화학적 스트레스를 가하는 것은 모발의 표면을 둘러싸고 있는 표피와 피질의 형태적 변화를 초래 하고, 모발을 구성하고 있는 케라틴 단백질의 화학구조에 변화를 가져 온다(Chang, 2003).

이러한 모발의 손상은 트리트먼트제를 도포하여 모표피의 정돈 과 빈공간을 채워줌으로써 모질을 개선할 수 있다. 현재 모발 손 상과 관련하여, 모발 제품에 적용되는 단백질의 효과(Lee \& Cho, 2011) 등과 같은 연구는 보고되었으나, 모발의 건강함과 관련된 요 소인 밀도, 굵기, 인장강도 등 모발의 물리적 특성과 미네랄간의 관 련성에 관한 연구는 아직 미흡한 실정이다. 따라서 본 연구에서는 시스틴, 라이신, 프롤린, 아르기닌, 글루탐산, 알라닌과 같은 아미 
노산이 첨가된 트리트먼트제로 시술 시 모발의 특성, 즉 손상된 모 발에서의 모표피 정돈정도, 아미노산 햠량, 인장강도를 측정함으 로써 모질 개선 효과를 확인하고자 하였다.

\section{Methods}

\section{1. 실험재료}

본 실험에서 사용한 모발 샘플은 2011년 3월부터 11월까지 서울 의 미용실에서 채취한 것으로 모근으로부터 $10 \mathrm{~cm}$ 떨어진 부위에 서 $15 \mathrm{~cm}$ 이상의 길이로 커트한 모발을 채취하여 사용하였다. 채 취 한 모발은 화학적 시술을 전혀 하지 않은 버진 헤어로 10 대 후 반의 4 명의 여학생 성모를 채취하였으며, 각 파트실험 별로 건강 모, 탈색모, 염색모의 굵기를 동일하게 측정하여 사용하였다. 모 발 굵기를 측정하는 측정기기는 Vernier caliper (CD-15 CPX; Mitutoyo, Japan)를 사용하였다.

본 실험에 사용한 시술제품은 최근 미용실에서 널리 사용하고 있는 모발 미용시술 전문가용 제품으로 시술하였다. 트리트먼트 제로는 (주)수안향장(Korea)에서 제조한 제품을 모든 시술에서 사 용하였으며, 트리트먼트제 조성표는 Table 1과 같다.

\section{2. 실험방법}

1) 탈색 및 염색

본 실험에서는 0.05-0.1 mm 굵기의 모발을 사용하였다. 탈색제 제 1 제 $3 \mathrm{mg}$ 과 제 2 제인 $6 \%$ 의 과산화수소 $3 \mathrm{~mL}$ 을 혼합하여 건강 모발 다발 3 개에 각각 1 회 도포한 다음 호일로 감싸, $10 \mathrm{~min}$ 동안 $50^{\circ} \mathrm{C}$ 가온 후 $10 \mathrm{~min}$ 동안 자연 방치하여 탈색 시술하였다(실내온 도 $25 \pm 1{ }^{\circ} \mathrm{C}$, 습도 $\left.50 \pm 10 \%\right) .3$ 개의 모발 다발 중 1 개는 모발을 물로 만 헹굼으로써 두피의 먼지나 때를 제거해 주는 플레인 샴푸(Kim et al., 2013)를 시행하였고, 또 다른 모발 다발 1 개는 플레인 샴푸 후 제조된 트리트먼트로 1회 도포, 마지막 모발 다발은 플레인 샴 푸 후 제조된 트리트먼트로 2 회 도포하여 $5 \mathrm{~min}$ 후 세척하여 플레 인 샴푸를 한 건강 모발과 비교하였다.

염색 시술에서는 실내온도 $25 \pm 1^{\circ} \mathrm{C}$, 습도 $50 \pm 10 \%$ 조건하에서 명도 $10 \mathrm{~N}$ 의 골드색으로 시술하였다. 건강 모발 다발 3 개에 각각 산화염모제 $10 \mathrm{~mL}$ 를 도포하여 $10 \mathrm{~min}$ 동안 $50^{\circ} \mathrm{C}$ 가온 후 $10 \mathrm{~min}$ 동안 자연 방치한 다음, 모발 다발 1 개는 플레인 샴푸, 또 다른 모발 다발 1 개는 플레인 샴푸 후 제조된 트리트먼트로 1회 도포, 마지막 모 발 다발은 플레인 샴푸 후 제조된 트리트먼트로 2 회 도포하여 $5 \mathrm{~min}$ 후 세척하여 플레인 샴푸를 한 건강 모발과 비교 측정하였다.

2) 모표피의 정돈정도

모발 손상 개선 정도를 확인하기 위하여 $\mathrm{MB}$ 염색법을 시행하였

\section{Table 1. Composition of hair-treatment agent}

\begin{tabular}{|c|c|c|c|}
\hline \multicolumn{2}{|c|}{ Division } & \multirow{2}{*}{ Ingredients } & \multirow{2}{*}{ Function } \\
\hline Phase & No. & & \\
\hline \multirow{5}{*}{ A } & 1 & Water & Water \\
\hline & 2 & Citric acid & $\mathrm{pH}$ adjuster \\
\hline & 3 & Betaine & Conditioning agent \\
\hline & 4 & Methylparaben & Preservative \\
\hline & 5 & Allantoin & Conditioning agent (soothing) \\
\hline \multirow{3}{*}{ B } & 6 & Stearamidopropyl dimethylamine & Conditioning agent \\
\hline & 7 & Steartrimonium chloride & Surfactant, antistatic agent \\
\hline & 8 & Cetearyl alcohol & Emulsion stabilizer, viscosity increasing agent \\
\hline \multirow{2}{*}{ C } & 9 & Cyclomethicone & Conditioning agent \\
\hline & 10 & Dimethicone & Hair conditioning agent, antifoaming agent \\
\hline \multirow{2}{*}{$\mathrm{D}$} & 11 & Hydrolyzed soy protein & Conditioning agent \\
\hline & 12 & Perfume & Fragrance \\
\hline $\mathrm{E}$ & 13 & Cetrimonium chloride & Surfactant, antistatic agent \\
\hline \multirow{6}{*}{$\mathrm{F}$} & 14 & Lysine (L-lysine hydrochloride) & Conditioning agent (amino acid) \\
\hline & 15 & Proline (L-proline) & Conditioning agent (amino acid) \\
\hline & 16 & Cystine (L-cystine) & Conditioning agent (amino acid) \\
\hline & 17 & Arginine (L-arginine) & Conditioning agent (amino acid) \\
\hline & 18 & Glutamic acid (L-glutamic acid) & Conditioning agent (amino acid) \\
\hline & 19 & Alanine (DL-alanine) & Conditioning agent (amino acid) \\
\hline
\end{tabular}


다(Kang \& Choe, 2007). 준비한 건강모, 염색모, 탈색모에 플레인 샴푸 혹은 플레인 샴푸 후 트리트먼트제를 사용하였다. 각 시료별 객관도, 신뢰도를 높이기 위해 굵기를 동일하게 한 모발 3 가닥씩 을 $\mathrm{MB}$ 로 염색한 후 $\mathrm{MB}$ 추출액의 흡광도를 측정하였다. 흡광도 측 정은 microplate reader (Synergy HT; BioTek Instruments, USA) 를 이용하여 $660 \mathrm{~nm}$ 에서 측정하였다. 또한, $\mathrm{MB}$ 염색의 흡착력을 높이는데 사용된 항온조는 high temp oven (Changshin Science, Korea), vortexer는 MTS 2/4 digital microtiter shaker (IKA ${ }^{\circledR}-$ Werke, Germany)를 사용하였다.

\section{3) 아미노산 함량}

아미노산 함량을 측정하기 위해 모발 $0.5 \mathrm{~g}$ 을 $18 \mathrm{~mL}$ 시험관에 넣 고 $6 \mathrm{~N}$ hydrogen chloride $3 \mathrm{~mL}$ 를 가하였다. 질소 가스를 수초 간 불어넣어 시험관 내부를 질소로 치환 후 밀봉하여 $121^{\circ} \mathrm{C}$ 에서 $24 \mathrm{~h}$ 동안 가수분해 하였다. 가수분해 된 시료를 아미노산 자동분석기 (S 433 Automatic Amino Acid Analyser; Sykam, Germany) 로 아미노산 함량을 측정하였다. 이동상으로는 $\mathrm{pH} 1, \mathrm{pH} \mathrm{2,pH}$ $3, \mathrm{pH}-\mathrm{RG}, \mathrm{R}-3$ 및 ninhydrin solution (Wako Pure Chemical Industries, Japan)을 사용하였다. 이때 사용한 칼럼(column)은 ion exchange column \#2622SC PH (Hitachi, Japan)를 사용하였 고, 칼럼 온도는 $50^{\circ} \mathrm{C}$ 이었으며, reaction chamber의 온도는 $135^{\circ} \mathrm{C}$ 로 유지하였다. 표준용액으로는 amino acid calibration mixture (AAS18; Sigma-Aldrich, USA)를 사용하였다.

\section{4) 인장강도}

인장강도 측정은 각 시료 당 모발 10 가닥을 $15 \mathrm{~cm}$ 로 동일한 길이 에서 만능재료강도시험기(Universal Testing Machine Model 4301; Instron, USA)로 측정하여 평균값을 구하였다. 인장시험의 측정 규격 은 섬유단사를 측정하는 한국산업규격 섬유의 인장강도 및 신도의 시험 방법(KS K0323)에 준하여 실시하였다. 측정값의 신뢰성을 위하여 각 시 편 당 10 회를 측정하고 측정값중 제일 높은 값과 제일 낮은 값을 제외한 8 회 측정값의 평균값을 구하였다. 인장시험 조건으로 clamping distance $20 \mathrm{~mm}$, 인장속도 $20 \mathrm{~mm} / \mathrm{min}$ 로 시험하여 인장강도를 측정하였다.

\section{Results and Discussion}

\section{1. 모표피의 정돈정도 확인}

모발의 특성상 퍼머나 탈색과 같은 알칼리제의 시술이 반복된 모발일수록 모발의 케라틴 단백질 및 간충물질이 유실된다고 알려 져 있는데 이는 모발이 손상될수록 $\mathrm{MB}$ 염색이 잘된다는 것을 의미 한다(Kang \& Choe, 2007). 트리트먼트 도포에 의한 모발 손상 개 선 여부를 알아보기 위하여 건강모, 탈색모, 염색모의 각 시료별로 플레인 샴푸 혹은 플레인 샴푸 사용 후 제조한 트리트먼트제 1 회, 2 회 도포한 다음, MB 염색을 통해 흡광도를 측정하였다(Table 2).

탈색모의 실험 결과를 살펴보면, 건강모와 탈색모의 플레인 샴 푸 후 모발의 흡광도 차이는 0.014 로 탈색모의 흡광도 값이 크다. 플레인 샴푸를 한 탈색모와 탈색모의 플레인 샴푸 후 트리트먼트 1 회를 한 모발과의 차이는 0.009 로 트리트먼트 1 회 한 모발의 흡광 도 값이 작게 나타났다. 또한, 트리트먼트 1 회 모발과 트리트먼트 2 회 모발의 차이는 0.002 로 트리트먼트 2 회 모발의 흡광도 값이 작 게 나타났다.

염색모의 실험 결과의 경우, 건강모와 염색모의 플레인 샴푸 후 모 발의 흡광도 차이는 0.065 로 염색모의 흡광도 값이 크다. 플레인 샴 푸를 한 염색모와 염색모의 플레인 삼푸 후 트리트먼트 1 회를 한 모 발과의 차이는 0.030 로 트리트먼트 1 회 한 모발의 흡광도 값이 작게 나타났다. 또한, 트리트먼트 1 회 모발과 트리트먼트 2 회 모발의 차이 는 0.003 으로 트리트먼트 2 회 모발의 흡광도 값이 작게 나타났다.

본 실험의 결과, 플레인 샴푸보다는 트리트먼트 1 회 도포한 흡광 도가 낮았고 1 회 도포하여 씻어 낸 것 보다는 2 회 도포하여 씻어 낸 시료의 흡광도 값이 낮았다. 트리트먼트 처리 후 모든 시료들의 흡 광도 값이 줄어 든 것으로 보아 이는 Kang \& Choe (2007)의 연구 결과와 일치할 뿐만 아니라, 모발 손상으로 모피질 층의 수분과 간 충물질이 빠져 나왔기 때문에 이 부분을 트리트먼트제가 채워준 것 으로 사료된다.

\section{2. 아미노산 함량 분석 결과}

탈색모와 염색모의 플레인 샴푸, 플레인 샴푸 후 트리트먼트제

Table 2. Hair surface arrangement of damaged hair by using hair-treatment agent

\begin{tabular}{|c|c|c|}
\hline Division & Sample & Absorbance \\
\hline \multirow{4}{*}{ Bleached hair } & Plain shampoo of healthy hair (once) & 0.016 \\
\hline & Plain shampoo of bleached hair (once) & 0.030 \\
\hline & Hair treatment after plain shampoo of bleached hair (once) & 0.021 \\
\hline & Hair treatment after plain shampoo of bleached hair (twice) & 0.019 \\
\hline \multirow{4}{*}{ Dyed hair } & Plain shampoo of healthy hair (once) & 0.026 \\
\hline & Plain shampoo of dyed hair (once) & 0.091 \\
\hline & Hair treatment after plain shampoo of dyed hair (once) & 0.061 \\
\hline & Hair treatment after plain shampoo of dyed hair (twice) & 0.058 \\
\hline
\end{tabular}


를 1 회 처리한 모발과 2 회 처리한 모발의 아미노산 함량을 확인하 였다. 탈색모의 아미노산 함량을 살펴보면 탈색 후 플레인 샴푸 시 아미노산 함량은 77,360.915 mg/100 g이며, 트리트먼트 1회 도 포 시 함량은 78,236.928 mg/100 g으로 플레인 샴푸보다 876.013 $\mathrm{mg} / 100 \mathrm{~g}$ 증가 하였다(Table 3). 트리트먼트 2회 처리 시 아미노 산 함량은 $79,646.646 \mathrm{mg} / 100 \mathrm{~g}$ 으로 트리트먼트 1회 처리보다 $1,409.718 \mathrm{mg} / 100 \mathrm{~g}$ 으로 증가한 것으로 나타났다.

모발 아미노산 중 주요 성분인 시스틴(cystine) 함량의 변화를 보 면 플레인 샴푸 시 8,246.583 mg/100 g이고 트리트먼트 1회 도포 시 $8,699.154 \mathrm{mg} / 100 \mathrm{~g}$ 으로 $452.571 \mathrm{mg} / 100 \mathrm{~g}$ 증가하고 트리트 먼트 2회 도포 시는 1회보다 $556.749 \mathrm{mg} / 100 \mathrm{~g}$ 증가함을 알 수 있 었다. 라이신(lysine)의 경우 트리트먼트제 1회 도포 값이 2,165.337 $\mathrm{mg} / 100 \mathrm{~g}$ 으로 플레인 샴푸보다 $94.690 \mathrm{mg} / 100 \mathrm{~g}$ 증가하고 트리 트먼트제 2회 도포 값이 $2,227.029 \mathrm{mg} / 100 \mathrm{~g}$ 으로 1회 도포보다 $61.692 \mathrm{mg} / 100 \mathrm{~g}$ 증가하였다.

프롤린(proline)의 경우 트리트먼트제 1 회 도포 값이 $5,589.572$ $\mathrm{mg} / 100 \mathrm{~g}$ 으로 플레인 샴푸보다 $32.325 \mathrm{mg} / 100 \mathrm{~g}$ 증가하고 트리 트먼트제 2회 도포 값이 5,789.273 mg/100 g으로 1회 도포보다 $199.701 \mathrm{mg} / 100 \mathrm{~g}$ 증가하였다. 아르기닌(arginine)의 경우 트리트 먼트제 1회 도포 값이 7,647.784 mg/100 g으로 플레인 샴푸보다 $41.536 \mathrm{mg} / 100 \mathrm{~g}$ 증가하고 트리트먼트제 2회 도포 값이 7,724.276 $\mathrm{mg} / 100 \mathrm{~g}$ 으로 1 회 도포보다 $76.492 \mathrm{mg} / 100 \mathrm{~g}$ 증가하였다. 글루탐산(glutamic acid)의 경우 트리트먼트제 1회 도포 값이 $12,303.811 \mathrm{mg} / 100 \mathrm{~g}$ 으로 플레인 샴푸보다 $6.729 \mathrm{mg} / 100 \mathrm{~g}$ 증가 하고 트리트먼트제 2회 도포 값이 $12,347.819 \mathrm{mg} / 100 \mathrm{~g}$ 으로 1 회 도 포보다 $44.008 \mathrm{mg} / 100 \mathrm{~g}$ 증가하였다. 알라닌(alanine)의 경우 트리 트먼트제 1회 도포 값이 2,690.212 mg/100 g으로 플레인 샴푸보다 $37.025 \mathrm{mg} / 100 \mathrm{~g}$ 증가하고 트리트먼트제 2회 도포 값이 2,695.124 $\mathrm{mg} / 100 \mathrm{~g}$ 으로 1회 도포보다 $4.912 \mathrm{mg} / 100 \mathrm{~g}$ 증가하였다.

탈색에 의해 손상도가 증가하면 시스틴 양이 가장 많이 감소한 다(Choi, 1999). 그러나 본 실험을 통해 아미노산이 유실된 모발에 트리트먼트 도포 시 시스틴과 프롤린 등의 아미노산 함량이 증가함 을 확인함으로써 아미노산의 보충으로 인해 인장강도 증가 등의 모 발 개선 효과를 볼 수 있을 것으로 판단하였다.

염색모의 아미노산 함량을 살펴보면 염색 후 플레인 샴푸 시 아 미노산 함량은 82,794.433 mg/100 g이며, 트리트먼트 1회 도포 시 아미노산 함량은 $84,208.271 \mathrm{mg} / 100 \mathrm{~g}$ 으로 플레인 샴푸보다 $1,413.838 \mathrm{mg} / 100 \mathrm{~g}$ 증가하였다(Table 4). 트리트먼트 2회 함량은 $88,915.486 \mathrm{mg} / 100 \mathrm{~g}$ 으로 트리트먼트 1회 보다 4,707.215 mg/100 $\mathrm{g}$ 증가한 것으로 나타났다.

모발 아미노산 중 시스틴 함량의 변화를 보면 플레인 샴푸 시 $11,443.097 \mathrm{mg} / 100 \mathrm{~g}$ 이고 트리트먼트 1회 도포 시 12,283.863 $\mathrm{mg} / 100 \mathrm{~g}$ 으로 $840.766 \mathrm{mg} / 100 \mathrm{~g}$ 증가하였고, 트리트먼트 2회 도 포 시 1회 보다 $677.651 \mathrm{mg} / 100 \mathrm{~g}$ 증가함을 알 수 있었다. 라이신

Table 3. Amino acid contents of bleached hair

(Unit: $\mathbf{m g} / 100$ g)

\begin{tabular}{|c|c|c|c|}
\hline Component Sample & $\begin{array}{l}\text { Plain shampoo of } \\
\text { bleached hair }\end{array}$ & $\begin{array}{r}\text { Hair treatment after plain } \\
\text { shampoo of bleached hair (once) }\end{array}$ & $\begin{array}{r}\text { Hair treatment after plain } \\
\text { shampoo of bleached hair (twice) }\end{array}$ \\
\hline Aspartic acid & $5,288.177$ & $5,185.986$ & $5,167.649$ \\
\hline Threonine & $5,875.582$ & $5,883.890$ & $5,838.049$ \\
\hline Serine & $7,495.873$ & $7,567.200$ & $7,684.062$ \\
\hline Glutamic acid & $12,297.082$ & $12,303.811$ & $12,347.819$ \\
\hline Proline & $5,557.247$ & $5,589.572$ & $5,789.273$ \\
\hline Glycine & $2,715.374$ & $2,746.072$ & $2,808.773$ \\
\hline Alanine & $2,653.187$ & $2,690.212$ & $2,695.124$ \\
\hline Cystine & $8,246.583$ & $8,699.154$ & $9,255.903$ \\
\hline Valine & $4,183.241$ & $4,193.845$ & $4,316.167$ \\
\hline Methionine & 450.196 & 455.389 & 476.403 \\
\hline Isoleucine & $2,401.021$ & $2,404.304$ & $2,477.813$ \\
\hline Leucine & $5,766.651$ & $5,803.703$ & $5,825.106$ \\
\hline Tyrosine & $1,902.684$ & $1,862.496$ & $2,041.040$ \\
\hline Phenylalanine & $1,774.156$ & $1,821.451$ & $1,814.822$ \\
\hline Histidine & $1,076.966$ & $1,216.722$ & $1,157.338$ \\
\hline Lysine & $2,070.647$ & $2,165.337$ & $2,227.029$ \\
\hline Arginine & $7,606.248$ & $7,647.784$ & $7,724.276$ \\
\hline Total & $77,360.915$ & $78,236.928$ & $79,646.646$ \\
\hline
\end{tabular}


의 경우 트리트먼트제 1 회 도포 값이 $2,492.317 \mathrm{mg} / 100 \mathrm{~g}$ 으로 플 레인 샴푸보다 $30.498 \mathrm{mg} / 100 \mathrm{~g}$ 증가하고 트리트먼트제 2회 도 포 값이 2,534.225 mg/100 g으로 1회 도포보다 $41.908 \mathrm{mg} / 100 \mathrm{~g}$ 증가하였다.

프롤린의 경우 트리트먼트제 1회 도포 값이 $6,024.272 \mathrm{mg} / 100$ $\mathrm{g}$ 으로 플레인 샴푸보다 $121.339 \mathrm{mg} / 100 \mathrm{~g}$ 증가하고 트리트먼트 제 2회 도포 값이 $6,720.216 \mathrm{mg} / 100 \mathrm{~g}$ 으로 1회 도포보다 695.944 $\mathrm{mg} / 100 \mathrm{~g}$ 증가하였다. 아르기닌의 경우 트리트먼트제 1 회 도포 값 이 7,709.600 mg/100 g으로 플레인 샴푸보다 $107.857 \mathrm{mg} / 100 \mathrm{~g}$ 증가하고 트리트먼트제 2회 도포 값이 8,068.070 mg/100 g으로 1 회 도포보다 $358.470 \mathrm{mg} / 100 \mathrm{~g}$ 증가하였다.

글루탐산의 경우 트리트먼트제 1 회 도포 값이 $12,253.529$ $\mathrm{mg} / 100 \mathrm{~g}$ 으로 플레인 샴푸보다 $1.794 \mathrm{mg} / 100 \mathrm{~g}$ 증가하고 트리 트먼트제 2회 도포 값이 12,371.283 mg/100 g으로 1회 도포보다 $117.754 \mathrm{mg} / 100 \mathrm{~g}$ 증가하였다. 알라닌의 경우 트리트먼트제 1회 도 포 값이 2,860.671 mg/100 g으로 플레인 샴푸보다 $62.137 \mathrm{mg} / 100$ $\mathrm{g}$ 증가하고 트리트먼트제 2회 도포 값이 3,043.301 mg/100 g으로 1 회 도포보다 $182.630 \mathrm{mg} / 100 \mathrm{~g}$ 증가하였다.

염색모의 경우 아미노산 함량이 줄어든 것은 모표피 세포 사이 를 연결하고 있는 세포막 복합체의 분리에 의해서 생긴 틈으로 환 원제 염모제가 침투하여 모발내의 단백질 구조를 변화가 일어나 생 긴 것으로 Seshadri \& Bhushan (2008)의 연구 결과와 일치한다. 그러나 본 실험의 경우 염색모에 트리트먼트제를 도포했을 때 아미 노산 함량이 증가함을 확인함으로써 제조된 트리트먼트제가 모발

Table 4. Amino acid contents of dyed hair

(Unit: $\mathbf{m g} / 100 \mathrm{~g}$ )

\begin{tabular}{|c|c|c|c|}
\hline Component Sample & $\begin{array}{r}\text { Plain shampoo of } \\
\text { dyed hair }\end{array}$ & $\begin{array}{l}\text { Hair treatment after plain } \\
\text { shampoo of dyed hair (once) }\end{array}$ & $\begin{array}{l}\text { Hair treatment after plain } \\
\text { shampoo of dyed hair (twice) }\end{array}$ \\
\hline Aspartic acid & $5,114.636$ & $5,233.326$ & $5,152.104$ \\
\hline Threonine & $5,739.303$ & $5,718.803$ & $6,195.199$ \\
\hline Serine & $8,194.724$ & $8,221.274$ & $8,825.025$ \\
\hline Glutamic acid & $12,251.735$ & $12,253.529$ & $12,371.283$ \\
\hline Proline & $5,902.933$ & $6,024.272$ & $6,720.216$ \\
\hline Glycine & $2,970.919$ & $2,972.587$ & $3,292.778$ \\
\hline Alanine & $2,798.534$ & $2,860.671$ & $3,043.301$ \\
\hline Cystine & $11,443.097$ & $12,283.863$ & $12,961.514$ \\
\hline Valine & $4,386.080$ & $4,394.817$ & $4,592.102$ \\
\hline Methionine & 528.663 & 525.445 & 598.107 \\
\hline Isoleucine & $2,373.632$ & $2,398.813$ & $2,536.609$ \\
\hline Leucine & $5,686.462$ & $5,713.113$ & $6,238.704$ \\
\hline Tyrosine & $2,125.509$ & $2,160.708$ & $2,320.409$ \\
\hline Phenylalanine & $1,830.789$ & $1,863.871$ & $2,024.444$ \\
\hline Histidine & $1,383.855$ & $1,381.262$ & $1,441.396$ \\
\hline Lysine & $2,461.819$ & $2,492.317$ & $2,534.225$ \\
\hline Arginine & $7,601 \cdot 743$ & $7,709.600$ & $8,068.070$ \\
\hline Total & $82,794.433$ & $84,208.271$ & $88,915.486$ \\
\hline
\end{tabular}

Table 5. Tensile strength of bleached hair and dyed hair

(Unit: kgf/mm²)

\begin{tabular}{|c|c|c|}
\hline Division & Sample & Mean value \\
\hline \multirow{4}{*}{ Bleached hair } & Plain shampoo of healthy hair (once) & 143.7 \\
\hline & Plain shampoo of bleached hair (once) & 109.3 \\
\hline & Hair treatment after plain shampoo of bleached hair (once) & 119.0 \\
\hline & Hair treatment after plain shampoo of bleached hair (twice) & 125.3 \\
\hline \multirow{4}{*}{ Dyed hair } & Plain shampoo of healthy hair (once) & 130.4 \\
\hline & Plain shampoo of dyed hair (once) & 117.9 \\
\hline & Hair treatment after plain shampoo of dyed hair (once) & 128.8 \\
\hline & Hair treatment after plain shampoo of dyed hair (twice) & 132.0 \\
\hline
\end{tabular}


개선 효과가 있는 것으로 판단하였다. 또한, 이 결과를 통해 아미 노산 함량이 증가할수록 인장강도와 신도가 증가한다는 Lim \& Ko (2012)의 선행 연구가 본 실험에서도 동일하게 적용될 지를 확인하 기 위해 인장강도 측정 실험을 진행하였다.

\section{3. 인장강도 측정 결과}

모발의 아미노산 함량과 인장강도, 신장률이 양의 상관성이 있 다는 Kim (2007), Lim \& Ko (2012)의 선행 연구를 바탕으로, 탈색 모와 염색모의 트리트먼트 사용시 아미노산 함량이 증가함을 확인 함으로써 트리트먼트 처리가 인장강도에 미치는 영향을 확인하고 자 실험을 진행하였다.

탈색모, 염색모의 플레인 샴푸, 플레인 샴푸 후 트리트먼트 1 회, 트리트먼트 2 회의 모발의 인장강도 결과는 Table 5 와 같다. 탈색모 의 경우 인장강도 실험 결과, 건강모보다 탈색 후 플레인 샴푸 한 모발의 인장강도 평균값이 34.4 정도 낮고 트리트먼트 1회 평균값 은 탈색모 플레인 샴푸 값보다 9.7 증가하였고, 트리트먼트 2회 시 술 값은 1 회 평균값보다 6.3 증가하였다. 탈색모는 알칼리성 용액 에 의해서 팽윤되고 화학물질이 피질 내로 전달되어 일어나는 화학 변화 등에 의해, 큐티클의 박리현상이 일어나거나 피질섬유의 탄력 성 및 유연성이 떨어지게 된다(Roh et al., 2009). 본 실험에서는 탈 색으로 감소된 모발의 인장강도가 트리트먼트 처리 후 증가함을 확 인함으로써 모발의 아미노산의 함량이 높을수록 인장강도가 증가 한다는 Kim et al. (2005)의 연구 결과와 동일한 결과를 얻었다.

염색모의 인장강도 결과는 탈색모와 같은 결과로 건강모보다 염 색 후 플레인 샴푸 한 모발의 인장강도가 평균값이 12.5 낮고 트리 트먼트 1회 시술 평균값은 염색모 플레인 샴푸 값보다 10.9 증가하 였고, 트리트먼트 2 회 시술 값은 1 회 시술 값보다 3.2 증가 하였다. 이는 제조된 트리트먼트제 처리로 인해 간충물질인 세포막 복합 체 및 기질 조직의 접착력이 향상된 것으로 판단되며, 계란 성분이 모발의 파손된 단백질을 보충해주어 모질 개선 효과 있다는 Lim (2000)의 결과와 같은 것으로 사료된다. 이와 같은 결과로 미루어 볼 때 트리트먼트제 도포로 인해 모질의 개선 효과가 나타나 탈색 모, 염색모의 인장강도가 증가하였음을 알 수 있었다.

\section{Conclusion}

모발은 탈색, 염색, 퍼머와 같은 화학적 미용 시술을 통해 모표 피, 모피질 성분이 용해되거나, 모표피의 들뜸 현상 등의 모발 손상 이 발생한다. 본 연구는 이러한 화학적 시술 후에 모발 관리 측면에 서 트리트먼트제를 제조하여 모발에 도포함으로써 모발의 모질 개 선 효과를 알아 보고자 하였다. 탈색모 및 염색모에 플레인 샴푸, 플레인 샴푸 후 트리트먼트 1 회, 트리트먼트 2 회 도포 후, 흡광도 측정, 아미노산 함량분석, 인장강도 측정을 통해 모질의 개선 효과
를 확인하여 다음과 같은 결론을 얻었다.

첫째, 탈색모, 염색모의 흡광도를 분석한 결과 플레인 샴푸보다 는 플레인 샴푸 후 트리트먼트 1 회 도포한 흡광도 측정값이 낮았 고, 트리트먼트 1 회 흡광도 값보다는 트리트먼트 2 회 측정값이 낮 아 모질의 손상도가 개선됨을 알 수 있었다.

둘째, 탈색모, 염색모의 아미노산 함량 분석 결과는 플레인 샴푸 보다 트리트먼트 1 회 도포한 모발의 아미노산 함량이 소폭 증가함 을 알 수 있었고, 트리트먼트 1회 도포보다는 트리트먼트 2 회 도포 시 아미노산 함량의 증가가 나타남으로써 트리트먼트의 모질 손상 개선효과를 확인할 수 있었다.

셋째, 인장강도 측정 결과 탈색모, 염색모에서 플레인 샴푸보다 는 트리트먼트 1 회 도포한 모발의 인장강도 값이 증가됨을 알 수 있 었고, 트리트먼트 1 회 인장강도 값보다는 트리트먼트 2 회 인장강도 값이 증가됨을 알 수 있어 모질의 손상도가 개선됨을 알 수 있었다.

이상의 결과로 보아 아미노산을 첨가하여 제조한 트리트먼트제 로 미용 시술 시 손상 모발의 모질 개선 효과가 있음을 확인하였고 가정용, 미용실 전문가용으로 제조하여 사용하는데 충분한 상품 가 치가 있다고 사료된다.

\section{References}

Chang BS. Fine structure of damaged hair shaft by daily treatment of heat for a beautiful face. Applied Microscopy, 33: 215-222, 2003.

Choi YH. A study on the cause and prevention of hair damage. Journal of the Kimcheon Science College, 25: 245-259, 1999.

Jeong TB, Ko UH, Kim HS, Jeon SG, BOFS International. Hair encyclopedia. Korean Hair Science Association, Seoul, pp152-165, 2000. (Kazuo D, 1992.)

Kang KY, Choe TB. Determination of hair damage by bleach agent and the effect of hair care treatment. Journal of the Korean Society of Cosmetology, 13: 955-963, 2007.

Kim HH, Lee JY, Lee CS. A study of hair dyeability of vegetable dye and black soybean. Journal of the Korean Society of Cosmetology, 11: 1-8, 2005.

Kim JS, Choe TB. Study on dyeing power pursuant to production of the first formulated type of acidic hairdye to utilize a kaoliang pigment. Asian Journal of Beauty and Cosmetology, 8: 201-210, 2010.

Kim JS, Kim CS, Kim YJ, Yoo SE. Hair science. Hunminsa, Seoul, pp110-158, 2010.

Kim JS, Kim CS, Lim DJ, Choi EJ, Jang HH, Shin JE. Scalp \& 
hair management. Kuhminsa, Seoul, pp95-109, 2013.

Kim JS, Lim DJ, Shin HC. Hair coloring mate. Ligline, Seoul, pp151-189, 2006.

Kim SH. A study on characteristics and amino acid composition of female hair according to age period. Journal of the Korean Society of Cosmetology, 13: 11111120, 2007.

Lee HN, Cho HS. A comparative analyze of wheat flour and egg white on scalp and hair damage in straight permanent. Asian Journal of Beauty and Cosmetology, 9: 9-18, 2011.

Lee KH, Lee GY, Kim MS, Kim GE, Kim YK, Chang BS. Morphological study of the bleaching agent and bleaching hair. Journal of Investigative Cosmetology, 2: 79-89, 2006.
Lim HJ, Ko KS. The effect of pura powder extracts in the permanent wave treatment. Journal of the Korean Society of Cosmetology, 18: 353-359, 2012.

Lim IS. A research to keep for health hair laying stress on a natural food and treatment with central figure. Journal of the Korean Society of Beauty and Art, 1: 79-86, 2000.

Roh JA, Chang BS, Choi TB. Study on the morphological change of straight permanent waved hair by tensile strength test. Applied Microscopy, 39: 49-56, 2009.

Seshadri IP, Bhushan B. In situ tensile deformation characterization of human hair with atomic force microscopy. Acta Materialia, 56: 774-781, 2008. 


\section{국문초록}

\section{트리트먼트제의 모질 개선 효과}

김주섭

상지영서대학교 피부미용과, 강원도 원주시, 한국

목적: 본 연구는 시스틴, 라이신, 프롤린, 아르기닌, 글루탐산, 알라닌과 같은 다양한 아미노산이 함유된 트리트먼트제 사용을 통해 손 상된 모발의 모질 개선 효과를 확인하는데 그 목적이 있다. 방법: 트리트먼트제의 모질 개선 효과를 확인하기 위하여, 탈색모와 염색 모에 플레인 샴푸 혹은 플레인 샴푸 후 트리트먼트 1 회 도포, 2 회 도포한 후 흡광도를 이용하여 모표피의 정돈정도를 확인하였으며, 모 발의 아미노산 함량과 인장강도를 측정하였다. 결과: 모표피의 정돈정도를 확인하기 위하여 탈색모와 염색모의 흡광도를 측정한 결 과, 플레인 샴푸보다는 플레인 샴푸 후 트리트먼트 1 회 도포한 흡광도 측정값이 낮았고, 트리트먼트 1 회 흡광도 값보다는 트리트먼트 2 회 흡광도 값이 낮아 모질의 손상도가 개선됨을 알 수 있었다. 탈색모와 염색모의 아미노산 함량을 확인한 결과, 플레인 샴푸, 플레인 샴푸 후 트리트먼트 1 회 도포, 2 회 도포 순으로 아미노산 함량이 증가함을 확인하였다. 아미노산 함량이 증가함에 따라 인장강도가 높 아진다는 기존의 연구결과를 바탕으로 트리트먼트 처리 후 인장강도를 확인해 본 결과, 아미노산 함량 결과와 동일하게 플레인 샴푸, 플레인 샴푸 후 트리트먼트 1 회 도포, 2 회 도포 순으로 인장강도가 증가하였다. 결론: 아미노산을 첨가하여 제조한 트리트먼트제를 사용할 경우, 손상 모발의 모질 개선의 효과가 있음을 확인하였으므로 가정용, 미용실 전문가용으로 제조하여 사용하는데 충분한 상품 가치가 있다고 사료된다.

핵심어: 트리트먼트, 모발, 개선, 모질, 큐티클

\section{참고문헌}

강갑연, 최태부. 탈색제에 의한 모발 손상 측정 및 모발 보호제 처리 효과. 한국미용학회지, 13: 955-963, 2007. 김순희. 연령기에 따른 여성모발의 특성 및 아미노산 조성에 관한 연구. 한국미용학회지, 13: 1111-1120, 2007. 김주섭, 김찬수, 김유정, 유세은. 모발과학. 훈민사, 서울, $\mathrm{pp} 110-158,2010$.

김주섭, 김찬수, 임대진, 최은정, 장현희, 신지은. 두피모발관리학. 구민사, 서울, pp95-109, 2013.

김주섭, 임대진, 신홍철. 헤어컬러링 메이트. 리그라인, 서울, pp151-189, 2006.

김주섭, 최태부. 고량색소를 첨가한 1제형 산성염모제 제조에 의한 염색력 연구. 아시안뷰티화장품학술지, 8: 201-210, 2010. 김홍희, 이주영, 이점숙. 식물성 염료와 검은 콩을 이용한 모발 염색에 관한 연구. 한국미용학회지, 11: 1-8, 2005.

노정애, 장병수, 최태부. 인장강도 측정에 의한 스트레이트 펌 모발의 형태학적 변화에 관한 연구. 한국현미경학회지, 39 :

49-56, 2009.

이경희, 이귀영, 김문선, 김금의, 김영길, 장병수. 탈색제와 탈색모발에 관한 형태학적 연구. 대한미용학회지, 2: 79-89, 2006. 이하나, 조희숙. 스트레이트퍼머넌트 시술시 소맥분과 난백분의 두피 - 모발 손상의 비교 분석. 아시안뷰티화장품학술지, 9 :

9-18, 2011.

임인숙. 건강모발을 유지하기 위한 연구: 천연식품과 천연 트리트먼트를 중심으로. 한국인체미용예술학회지, 1: 79-86, 2000. 임혜자, 고경숙. 퍼머넌트 웨이브 시술시 잠용분 추출물이 모발에 미치는 효과. 한국미용학회지, 18: 353-359, 2012. 장병수. 미용을 위한 일상적인 열처리에 의해서 손상된 모발의 미세구조. 한국현미경학회지, 33: 215-222, 2003. 정태봉, 고운하, 김한식, 전상구, 봅스 인터내셔날. 모발대전과. 한국모발과학협회, 서울, pp152-165, 2000. (大門一夫, 1992.) 최연희. 모발 손상 원인과 모발관리에 관한 연구. 김천과학대학 논문집, 25: 245-259, 1999. 


\section{中文摘要}

\section{护发品改善发质的效果研究}

金周炫

尙志嶺西大學皮肤美容科，江原道原州市，韩国

目的: 含有胱氨酸、赖氨酸、脯氨酸、精氨酸、谷氨酸和丙氨酸等氨基酸的护发品使用在损伤的头发时，探索其发质改善 效果。方法: 为了确认头发改善效果, 对脱色头发和染色头发分别进行洗发剂洗发, 洗发剂洗发后用护发品处理一次, 洗 发剂洗发后用护发品处理两次之后，分别测定其吸光度，确定毛表皮的整理程度、头发的氨基酸含量及头发拉伸强度。 结果: 为了确认毛表皮的整理程度, 测定脱色头发和染色头发的吸光度结果, 用洗发剂洗发后用护发品处理一次的吸光度值 比只用洗发剂洗发的吸光度值低，用洗发剂洗发后用护发品处理两次的吸光度值比洗发剂洗发后用护发品处理一次的吸光度 值低，从而确认发质的改善效果。脱色头发和染色头发的氨基酸测定结果，按洗发剂洗发、洗发剂洗发后用护发品处理一 次、洗发剂洗发后用护发品处理两次的顺序氨基酸的含量也逐渐增加。随着氨基酸含量的增加，拉伸强度也会增加的研究结 果, 用护发品处理后的拉伸强度与氨基酸含量一样, 按洗发剂洗发、洗发剂洗发后用护发品处理一次、洗发剂洗发后用护发 品处理两次的顺序拉伸强度也逐渐增加。结论: 在损伤头发上利用含有氨基酸的护发品时，损伤头发的发质明显得到改善。 因此分别制造家庭用以及美容院专业人士使用的护发品，其前景充分具有商业价值。

关键词: 护发品，头发，改善，发质，毛表皮 